\title{
PARTIDOS E REPRESENTAÇÃO POLÍTICA: DESAFIOS PARA A CONSTRUÇÃO DE UMA DEMOCRACIA CIDADÃ
}

Daiane Sandra TramontinI

Doutoranda em direito pelo Programa de Pós-Graduação em Direito da Universidade Federal de Santa Catarina. E-mail: daianetramontini@gmail.com

Orides MezZaroba

Professor nos Programas de Graduação e Pós-Graduação em Direito da Universidade Federal de Santa Catarina. Colaborador no Programa de Mestrado da Uninove SP. Pesquisador de Produtividade do CNPq.

\section{Resumo}

A democracia representativa encontra-se cada vez mais minada por conta do gradativo processo de fragmentação da soberania e da fragilidade da política atual. O que leva a uma tentativa de moralizaçáo política, por vezes pelo Judiciário, que utilizando-se de ativismos, deixa sua passividade institucional e legisla desde normas gerais a abstratas. $\mathrm{O}$ presente trabalho busca analisar a representação política como instrumento para fortalecimento da cidadania, aliada ao papel dos Partidos Políticos, como corpos intermediários entre o povo e o Estado, que irão canalizar a vontade popular, na construção democrática e para a garantia de direitos fundamentais.

\section{Palavras-chave}

Democracia; Representação Política; Partidos Políticos; Cidadania.

\section{Resumen}

La democracia representativa es cada vez más socavada por el proceso gradual de la fragmentación de la soberanía y la fragilidad de la política actual. Esto lleva a un intento de moralizar la política, a veces por el poder judicial, que utilizando el activismo, abandona su pasividad institucional y legisla desde normas generales hasta abstractas. En este trabajo se analiza la representación política como un instrumento para fortalecer la ciudadanía, junto con el papel de los partidos políticos, como órganos intermediarios entre el pueblo y el Estado, que canalizarán la voluntad popular, en la construcción democrática y para la garantía de los derechos fundamentales. 


\section{Palabras clave}

Democracia; Representación Política; Partidos Políticos; Ciudadanía.

\section{Introdução}

É por meio da representação politica que fundamentos como a cidadania, a soberania popular, o pluralismo politico tomam forma e se concretizam. É a representação política que vai proporcionar a efetivação da soberania popular, que se dará, nos termos do parágrafo único do artigo primeiro da Constituição Federal do Brasil, através de representantes eleitos ou diretamente. E são os Partidos Políticos, que constituem corpos intermediários entre o povo e o Estado, que irão canalizar a vontade popular, fazendo parte da vida da sociedade e fundamentais para a construção democrática.

Não há como se pensar em Estado Democrático de Direito, mais especificamente em Estado Democrático Constitucional de Direito, sem a presença da representação política, da cidadania e dos Partidos.

Contudo, o modelo clássico de Estado de Direito encontra-se em crise, a democracia representativa, cada vez mais minada por conta do gradativo processo de fragmentação da soberania. Em decorrência fragilidade política atual de muitos países, como o Brasil, na tentativa de moralização política, o Judiciário, muitas vezes, utilizando-se de ativismos, deixa sua passividade institucional e passa a legislar, desde normas gerais a abstratas. Apesar de toda a corrupção, do apelo pela moralização, o que o Judiciário esta fazendo vai de encontro ao Estado Democrático de Direito, e à representação política e a cidadania como fundamento da República Federativa do Brasil.

A transformação da sociedade e do Estado é nítida e tem interferido diretamente no ritmo das relaçóes intersubjetivas, e tem em muito ditado um novo ritmo, fazendo com que o Estado precise oferecer respostas às demandas sociais de modo cada vez mais célere.

Tratar da cidadania, como fundamento da representação política e do próprio Partido, como canal de integração social, é de essencial importância para o fortalecimento da democracia e para a garantia de direitos fundamentais. De forma que, buscar-se-á com o presente trabalho, demonstrar a importância desses institutos, inseridos no âmbito do Direito Constitucional, como fortalecimento da democracia representativa e da cidadania.

Para tanto, considerando-se tratarem de matérias atinentes ao âmbito constitucional, serão abordados os aspectos relacionados ao direito constitucional e à teoria garantista, bem como a relação entre a representação política e o Partido Político, também no viés dos direitos políticos, com a cidadania e a democracia. 


\section{Direito Constitucional e Constitucionalismo: Uma Relação com os Pilares do Estado Brasileiro}

É na Constituição Federal que se encontram positivadas as regras basilares da representação política, dos partidos políticos e da cidadania. Não há como tratar desses temas, sem o estudo constitucional da formação da Democracia, da representação, da soberania popular, do pluripartidarismo e da divisão dos poderes, princípios fundamentais da Constituição.

No Direito Constitucional serão encontradas as regras atinentes ao funcionamento e organização do Estado, sendo este Direito Público fundamental, que se refere "diretamente à organização e funcionamento do Estado, à articulação dos elementos primários do mesmo e ao estabelecimento das bases de sua estrutura política" (SILVA, 2010, p. 3335). Hesse (1991, p. 4) vai trabalhar com uma perspectiva jurídica e de força normativa da Constituição, de forma que ela passa a ter "força ativa" que vai influenciar na realidade política e social da sociedade.

A formação do Estado de Direito e do constitucionalismo, foi fortemente influenciado pelos movimentos contratualistas, que tem seus ícones em Jean-Jacques Rousseau, Thomas Hobbes e John Locke. Contudo, é com o constitucionalismo liberal do século XIX que o Estado de Direito se consagra, cita Moares (2011, p. 13), com destaque para as Constituiçóes de Cádis, de 19 de março de 1812, a Constituição Portuguesa de 23 de setembro de 1822, a Brasileira de 25 de março 1824 e a Belga de 7 de fevereiro de 1831.

O Estado de Direito surge "como expressão jurídica de uma democracia liberal", estando à democracia no âmbito mais amplo. Silva (2010, p. 112) ressalta que é com o Estado Democrático de Direito que serão reunidos aspectos do Estado de Direito e do Estado Democrático. O Estado Constitucional é, segundo Moraes (2011, p. 14), "uma das grandes conquistas da humanidade", que se completa como verdadeiro Estado, quando de veste de um Estado Democrático de Direito.

Teorias importantes na formação do pensamento jurídico fizeram parte da história pretérita e recente do constitucionalismo. Dentre elas, aqui será dado destaque ao constitucionalismo garantista, cunhada por Ferrajoli (2012, p. 19), que surge como um contraponto a teoria dos princípios e seguindo uma linha de direito como garantia, baseada numa perspectiva racional-positivista faz uma releitura do positivismo clássico. Para Ferrajoli (2012, p. 19) considerando aquilo que é determinado "constitucionalmente como vinculante e inderrogável”, o garantismo poderá ser caracterizado como um sistema jurídico, no qual constará a previsão da "submissão (inclusive) da legislação a norma relativas à produção não só formais, relativas a procedimentos (ao quem e ao como), mas também materiais, relativas aos conteúdos das normas produzidas (ao que se deve decidir e ao que não se deve decidir).” 
Segundo o Ferrajoli (2012, p. 26-27), esse constitucionalismo que ele também denominou de "jus-positivista", é uma mudança de paradigmas do velho juspositivismo, "enquanto positivamente normativo nos confrontos com a própria normatividade positiva e enquanto sistema de limites e de vínculos substanciais, relativos ao 'quê', em acréscimo àqueles somente formais, relativos ao 'quem' e ao 'como' das decisóes”.

O que se verifica com Ferrajoli (2012, p.25) é um reforço do positivismo jurídico kelseniano, no qual se busca uma construção de leis "de atuação, de idôneas garantias e de instituiçóes de garantias". Streck (2012, p.60) ao tratar do pensamento do autor, ressalta que essa perspectiva garantista vai "demonstrar" que a democracia somente se faz "pelo e através do direito".

Ferrajoli (2012, p. 25-26) vai afirmar que os direitos, sejam os fundamentais assim como os demais, versam sobre expectativas positivas ou negativas, sobre obrigaçóes ou proibições. Nesse sentido corresponderiam a garantias primárias, ou seja, as proibiçôes e obrigações, e garantias secundárias, quais sejam a necessária reparação ou sanção judicial de lesão aos direitos. Para o autor, a ausência de garantias irá provocar lacunas que colocarão em risco a efetivaçáo dos direitos.

O modelo garantista, com sua releitura do positivismo clássico, mostra-se como importante e vantajoso instrumental à sociedade contemporânea, que vê seus direitos muitas vezes vilipendiados por ativismos judiciais.

Partindo da premissa de que a "Constituição é principiológica porque há um conjunto de princípios que conformam o paradigma constitucional, de onde exsurge o Estado Democrático de Direito" (STREK, 2012, p.69), o pacto original de 1988 fundou o Estado brasileiro sob a dimensão do direito, sobre três grandes pilares na forma federativa, com base republicana de governo e fixou-lhe o regime político democrático (JARDIM, 1998, p. 99, 102, 125).

Estado Democrático de Direito, no ordenamento jurídico brasileiro é proclamado, no art. $1^{\circ}$ da Constituição Federal ${ }^{1}$, que prevê um Estado baseado em normas democráticas, por meio de eleiçôes livres e periódicas pelo povo, e garantia de direitos fundamentais. Assim, a organização política foi estruturada sobre um viés no qual se estabeleceu o modo de aquisição e exercício do poder, os direitos fundamentais e as respectivas garantias (SILVA, 2010, p. 38- 43). Três grandes pilares dão forma o Estado Democrático Brasileiro, quais sejam a forma federativa, a base republicana, e o regime democrático.

1 Art. 10 A República Federativa do Brasil, formada pela uniāo indissolúvel dos Estados e Municípios e do Distrito Federal, constitui-se em Estado Democrático de Direito e tem como fundamentos:I - a soberania;II - a cidadania;III - a dignidade da pessoa humana;IV - os valores sociais do trabalho e da livre iniciativa;V - o pluralismo político.Parágrafo único. Todo o poder emana do povo, que o exerce por meio de representantes eleitos ou diretamente, nos termos desta Constituição. 
A forma federativa do Estado caracteriza-se pela união de "coletividades públicas dotadas de autonomia político constitucional, autonomia federativa” (SILVA, 2010, p. 99). Esse formato, no âmbito do direito constitucional propriamente dito, nasceu com a Constituição norte-americana de 1787. No Brasil, esse formato surgiu em 1889 com a proclamação da República que, considerando-se os formatos anteriores ${ }^{2}$, pequenas mudanças ocorreram e com reflexos mínimos. Habib (1994, p.28) destaca que longe de alcançar o verdadeiro programa a que deveria restringir-se a implantação da República passou longe de reais mudanças, o maior exemplo disso é o restabelecimento do coronelismo, "com todas as suas mazelas e de nefastas consequências para o país, consolidando-se a partir dos dois primeiros presidentes civis e repercutindo até 1930".

Segundo Silva (2010, p. 102-103), o princípio republicano passou por uma "evolução constitucional", e hoje se configura como "princípio fundamental da ordem constitucional". Bauman (2000, p. 190) entende que a ideia republicana não impóe um modelo de vida correta, mas "a capacitação dos cidadãos para discutirem livremente os modelos de vida de sua preferência e praticá-los. A república é uma ampliação, não uma redução de opções - seu objetivo é aumentar, não limitar as liberdades individuais”. Essa vertente do ideal republicano encontra especial guarida em Constituiçóes como a Carta brasileira de 1988 .

Desse cidadão-individuo é exigida a escolha do candidato e o cuidado necessário da opção, o voto periódico, por si só não basta. A cidadania ativa é cada vez mais invocada, para que haja uma democracia para além dos pleitos eleitorais. Além dos deveres cidadãos, o princípio republicano exige um sentimento constitucional.

Salienta Bauman (2000, p. 171) que a ideia republicana, "coloca o questionamento crítico no cerne da participação comunitária; os cidadãos fazem parte da república através da ativa preocupação com os valores promovidos ou desprezados pelo Estado". Muito devido ao esvaziamento da política, ou a descrença na democracia.

Nesse ponto que a democracia é cada vez mais destacada e estudada, como forma de fortalecimento do Estado e das garantias constitucionais. A democracia, o governo do povo, é instituto que tem na soberania popular o seu primado. É por meio dos direitos

2 O Brasil Colônia, período que compreende os anos de 1500 a 1815, primeira fase de exploração do território brasileiro, com estabelecimento de doze capitanias hereditárias, que criaram os primeiros núcleos de povoamento ocidental na região. "A dispersão do poder político e administrativo era assim completa, sem elo que permitisse qualquer interpenetração, salvo apenas a fonte comum que era a metrópole”. (SILVA, 2010, p. 70). Com a vinda da família real portuguesa para o Brasil em 1808 inicia-se o Brasil Império, período de mudanças como abertura dos os portos, criação de repartiçôes para a administração, os primeiros tribunais, o Banco do Brasil, a Casa da Moeda, a Biblioteca Nacional etc, as discussóes políticas são mais enérgicas, quando em 1822 é proclamada a independência. Surgindo em 1824 a primeira Constituição brasileira promulgada que centraliza o poder na figura do monarca através do "Poder Moderador". 
políticos que a soberania popular é exercida e formam a base do regime democrático ao conferirem ao cidadão nacional o direito de participação na vida política de seu país, no qual se veem investidos com os poderes necessários para participar da vida pública, direta ou indiretamente, através de seu voto.

Velloso e Agra (2014, p. 19-21) ressalvam que é o povo o "supremo juiz das coisas no do Estado”, para os autores, é ele que rege o destino da organização politica. Silva (2010, p. 125) entende a Democracia como um conceito histórico, que se caracteriza por denotar o meio e forma de realizaçáo de valores essenciais e de direitos fundamentais. Para o autor, é um princípio que desponta para um regime político que tem suas bases na participação popular. $\mathrm{O}$ princípio democrático ${ }^{3}$ é expressamente previsto na Constituição Federal de 1988.

O mais antigo regime democrático é o da democracia direta, modelo desenvolvido pelos gregos em suas cidades-estados ${ }^{4}$. $\mathrm{Na}$ democracia direta, a soberania popular é exercida sem intermediários ou representantes. Esse modelo logo se esgotou com fim das cidades-estados e pelo aumento populacional, cada vez mais se tornava impossível a participação direta. Atualmente é quase impossível, considerando que não há forma de catalisar a toda a vontade da população. Borja (1991, p. 126), ao tratar do assunto ressalta que esse governo direto, pensado como governo do povo pelo povo, "é definitivamente uma ficção, carente de conteúdo real e de possibilidade prática, haja vista que é impossível que a multidão exerça por si mesma as funçôes diretivas do Estado”.

A democracia representativa ou indireta, onde o povo elege seus representantes para que, em seu nome, governem o país. Silva (2010, p. 136-137) destaca que é na democracia representativa que o povo, que possui a fonte primária do poder, periodicamente, elegerá representantes para dirigir o Estado. É na democracia representativa que será fortalecida a democracia participativa, com o desenvolvimento da cidadania. A democracia semidireta ou participativa elege instrumentos para que o povo participe das tomadas de decisões, no Brasil temos o exemplo do plebiscito, referendo, a iniciativa popular, a ação popular, constitucionalmente garantidos.

Importante salientar que a democracia brasileira, embora seja sua maior influência, não é puramente representativa. A Carta Magna prevê formas de representação direta, que permite, de certa forma a intervenção cidadã na tomada de decisóes políticas. Tal previsão esta contida no art. 14 da Constituição são elas o plebiscito e o referendo, tidas como consultas populares, e iniciativa popular de leis.

3 Expressamente previsto no preâmbulo e art. 1º da Constituiçăo Federal de 1988

4 Definição de Cidades-estados ou pólis: "Por Pólis se entende uma cidade autônoma e soberana, cujo quadro institucional é caracterizado por uma ou várias magistraturas, por um conselho e por uma Assembleia de cidadãos (politai)." (BOBBIO, 2006, p. 949) 
Para Schumpeter, trabalhando com o conceito de democracia no aspecto procedimental, "o método democrático é aquele arranjo institucional para se chegar a decisôes políticas em que os indivíduos adquirem o poder de decidir por meio de uma luta competitiva pelo voto da população" (SCHUMPETER apud KINZO, 2004, p. 36). Segundo Kinzo (2004, p. 24), esse conceito de democracia, busca identificar no sistema político uma forma de organização com base em procedimentos que permitam a escolha competitiva de líderes mediante a participação popular.

De forma que a Constituição de 1988 combina a democracia representativa com instrumentos de participação direta, embora esta última de forma ainda muito insipiente. Mas tem nas eleiçóes não apenas a possibilidade de alternância do poder, mas a representatividade que dá expressão ao sistema democrático, e a necessária responsividade de um governo que atue em resposta às demandas sociais.

Com a teoria garantista, propóe-se, como elucida Marcellino Jr (2009, p. 49), um novo conceito de democracia, qual seja a democracia substancial ou social. Continua o autor explicando que "o Estado de direito mune-se de garantias específicas, não somente liberais, mas também sociais", são caracterizadas pelos Direitos Fundamentais, e a democracia formal ou politica, "consistirá no Estado de direito representativo, calcado no princípio da maioria como referencial de legalidade”.

Ou seja, o povo e o poder legislativo são limitados pela lei, pelos direitos fundamentais. É inevitável que a democracia e a liberdade individual estejam imbrincados, bem como deve o poder ser na existência de direitos fundamentais limitadores.

Ferrajoli (2010, p. 1), em artigo intitulado Jurisdição e Consenso, relata que para a sobrevivência da democracia, e para legitimação de decisôes, as Constituiçôes foram formadas dentro do que ele chama de "esfera do indecidível" que engloba "a lesão ou restrição dos direitos de liberdade que nenhuma maioria pode legitimamente decidir" e "a satisfação de direitos sociais". Assim, segundo o autor, o que fica fora dessa esfera é considerado "esfera do decidível, isto é, das decisóes legitimadas pelo consenso popular, através da representação política". As decisões políticas de governo, segundo Ferrajoli encontramse limitadas nos direitos fundamentais constitucionalmente expressos.

A partir do momento, que direitos constitucionalmente garantidos, começam a ser vilipendiados por decisóes judiciais, muitas vezes baseada em preceitos morais, passa-se a viver numa constante insegurança jurídica.

Isso, tem se mostrado frequente no sistema jurisdicional brasileiro. A Democracia no Brasil tem como fundamento a representação política, que se da por intermédio dos Partidos Políticos, associações de direito privado, que possuem prerrogativas e garantias constitucionalmente garantia par ao exercício do seu papel fundamental de interlocutor da cidadania. 


\section{Os Direitos Políticos, a Representação Política e os Partidos: A Relação com a Cidadania}

A característica essencial da democracia representativa está na concepção de um processo formal de escolha de representantes que "pressupóe um conjunto de instituiçôes que disciplinam a participação popular no processo político, que vem a formar os direitos políticos que qualificam a cidadania, tais como as eleiçôes, o sistema eleitoral, e os partidos políticos, conforme constam do art. 14 e 17 da Constituição” (SILVA, 2010, p.137).

Os direitos políticos são tidos como os meio imprescindíveis ao exercício da cidadania, e da soberania popular. É por meio dos direitos políticos positivos que o individuo pode intervir na estrutura governamental e participar do processo político (Silva, 2010).

São os direitos políticos para Conde (1999, p. 416) prorrogativas atreladas à cidadania, quando outorgam à população o direito de participar da escolha das decisóes políticas, é um direito e um dever do povo. Kelsen (1998, p. 125) vê nos direitos políticos a possibilidade do cidadão participar da criação da ordem jurídica mediante a participação do governo. Para Canotilho (2008, p. 394) os direitos políticos somente são "atribuídos aos cidadãos ativos".

São um desdobramento do princípio democrático, que na forma do art. $1^{\circ}$, parágrafo único, da Constituição Federal de 1988, determina que "o poder emana do povo, que o exerce por meio de representantes eleitos ou diretamente" (SILVA, 2010, p. 345). De forma que é por meio dos direitos políticos positivos que se regem: o acesso ao sufrágio ativo e passivo - direito de votar e ser votado nas eleiçóes, incluindo as condições de elegibilidade constitucionais e o direito de voto nos plebiscitos, nos referendos, ao lado de outros direitos de participação popular em processos legislativos e políticos, como firmar e propor projetos de lei de iniciativa popular, propositura de ação popular e organização e participação nos Partidos Políticos.

Conforme define Silva (2010, p. 137, 138, 368), "na democracia representativa a participação popular é indireta, periódica e formal, por via das instituiçóes eleitorais que visam a disciplinar as técnicas de escolha dos representantes do povo”. Isso significa que eleger constitui um ato de decisão política por excelência, pois o cidadão expressa uma preferência entre alternativas, além de conferir legitimidade à determinada política governamental, pois, tanto aderiu à determinada plataforma política do candidato, quanto consentiu na ascensão ao poder de determinado Partido Político, cujo ideário pressupóese ser impresso por meio das açóes do mandatário.

De forma que os Partido Políticos, são por excelência, os instrumentos, dentro da Democracia, para a participação política, e a concretização da cidadania. 
A cidadania é um fundamento da Republica Federativa do Brasil, expressamente prevista no art. $1^{\circ}$, inciso II da Constituiçáo Federal juntamente com a soberania, a dignidade humana, os valores sociais do trabalho e da livre iniciativa. É um conceito histórico que varia no tempo e no espaço, e segundo Saes (2000, p.1), a cidadania juntamente com a globalização, funcionam como um "mito", que emergem "tal impacto emocional que chegam ao ponto de provocar a paralisia do pensamento".

O historiador Pinsky (1983, p. 9), vê no conceito de cidadania um conjunto de direitos, sejam os civis, políticos e sociais, explica o autor que "os direitos civis e políticos não asseguram a democracia sem os direitos sociais”. Para Santos (1995, p.12) a cidadania é um "mecanismo que regula a tensão entre a sociedade civil e o Estado". Já Bittar (2004, p.9-8) trabalha com um conceito politico-jurídico de cidadania. Para o autor, ser cidadão é "ser parte de um Estado soberano", seja pelo critério sanguíneo ou nacional (ius sanguini e ius soli), gozando dos direitos políticos, com direito a votar e ser votado.

Denota-se que a cidadania, pode ser vista não somente no aspecto politico-jurídico, como uma condição de usufruto de direitos políticos, como uma relação entre o Estado e a Sociedade Civil, a esfera pública e a privada, mas também deve ser encarada para além desses conceitos, como uma construção cultural e histórica.

De não se olvidar, que também como fundamento da Republica Federativa do Brasil (art. $1^{\circ}$, inciso I, da Constituição Federal) ${ }^{5}$ esta a soberania que somente se exerce porque se da legitimamente pela soberania popular, e o pluralismo político, previsto no inciso $\mathrm{V}$ do art. $1^{\circ}$ da Carta Magna. Tal pluralismo é caracterizado especialmente pela realidade da sociedade, ou seja, uma sociedade pluralista, com categorias sociais diversas, de classes, cultural, ideológico (SILVA, 2010, p. 143).

A ideia de pluralismo político passou a ganhar ênfase em 1861 na obra de John Stuart Mill - Consideraçóes sobre o Governo Representativo, na qual o autor destaca que em uma democracia "qualquer seção deve ser representada, [...] proporcionalmente", onde a “maioria dos eleitores terá sempre a maioria de representantes, mas a minoria dos eleitores deverá ter uma minoria de representantes” (MILL, 1964, p. 60-61).

Com intrínseca relação com a representação, política e a formação da cidadania, esta o princípio da separação dos poderes que foi desenvolvido por Montesquieu, no seu livro $O$ Espírito das Leis, no qual um bom governo somente se sustentaria se divididos os poderes em Legislativo, Executivo e Judiciário. Esse modelo que balizou e determinou a representação politica "como uma de suas implicaçôes mais imediatas" (MEZZAROBA, 2004, p. 47).

5 Art. 10 A República Federativa do Brasil, formada pela união indissolúvel dos Estados e Municípios e do Distrito Federal, constitui-se em Estado Democrático de Direito e tem como fundamentos: I - a soberania; 
Montesquieu via duas características essenciais para a demonstração da separação dos poderes, quais sejam a liberdade política e a ideia de representação política. (MONTESQUIEU, 2000, p. 134-138). E é por meio da representação política que fundamentos como a cidadania, a soberania popular e o pluralismo político tomam forma e concretizam. É a representação política que vai proporcionar a efetivação da soberania popular, que se dará, nos termos do parágrafo único do artigo primeiro da Constituição Federal, através de representantes eleitos ou diretamente.

Arendet (1965, p. 239-240) destaca que a representação implica na própria dignidade do domínio público. Segundo a autora somente com a participaçấo democrática poderia haver uma resposta para a questão entre mandatos e independência, onde o representante é um mero agente de interesses privados. Para a autora, ou o povo entra numa "letargia, precursora da morte da liberdade pública" ou preserva a resistência.

A representação, segundo Pitkin (2006, p. 16) é em larga monta, "um fenômeno cultural e político, um fenômeno humano". Jellinek (1981, p. 429) vê a representação como "fundamentalmente jurídica", onde a vontade de um (ou muitos) sobrepóe-se sobre a de outros.

Hamilton, Madison e Jay (2003, p. 64) na obra O Federalista, ressaltam que a representação vai depurar as perspectivas públicas, pois será por meio de um corpo escolhido de cidadãos, o qual deverá ter sabedoria e prudência para escolher o real interesse do país, e que, "pelo seu patriotismo e amor da justiça, estarão mais longe de o sacrificar a consideraçóes momentâneas e parciais”. Para os autores, somente em governo assim, no qual a vontade pública é expressa pelos representantes, terá condiçôes de ter harmonia com os interesses públicos.

Em decorrência da representação política, que os Partidos Políticos vão agir em nome da sociedade. Eles no ordenamento jurídico e político exercessem grande influência e são de incontestável importância para a democratização, posto que são instrumentos de ligação entre o Estado e a sociedade. O processo de escolha de representantes é, sobretudo, efetivado por meio dos Partidos Políticos, já que uma das condiçóes de elegibilidade (art. 14, $\$ 3^{\circ}$, inciso V, da Constituição Federal) é o candidato estar filiado a um Partido Político. O que se nota é que essas agremiaçôes "respondem diretamente pela formação da classe que irá dirigir o país, por deterem constitucionalmente o monopólio eleitoral” (KLEIN, 2002, p. 23).

Os Partidos Políticos estão associados não apenas à esfera eleitoral, como também ao planejamento e formulação de políticas que legitimem tais organizaçôes como atores do processo político. São agentes do processo representativo democrático, respaldados pela soberania e o voto popular, são o canal de expressão de interesses entre a sociedade e o Estado (KINZO, 2004, p. 24-25). 
Deve o Partido Político ser o "promotor uma grande síntese social", e ter "uma máquina organizativa e um programa político estruturado e articulado", que farão o diferencial. Por meio do Partido Político que se formam a consciência política da coletividade (CERRONI, 982, p.13, 53).

Sem dúvidas, os Partidos Políticos, tornaram-se instituiçóes jurídico-políticas de extrema importância para os Estados Democráticos e para a representação da vontade política dos cidadãos. Através dessas organizaçóes que se busca edificar a vida política e o consenso na sociedade, são elas o instrumento essencial da cidadania e da democracia representativa. E devem retomar esse papel no seio da sociedade, para que esse estigma corruptor não perpasse ao seu papel fundamental.

\section{0 Ativismo Judicial e os Partidos Políticos: Desafios na Construção da Cidadania}

Como visto, a divisão dos poderes vai confiar cada função governamental (executiva, legislativa e jurisdicional) a um órgão distinto. A separação dos poderes tem como fundamento a especializaçâo funcional e à independência orgânica, ou seja, "cada órgáo é especializado no exercício de uma função" e é cada órgão deve ser "efetivamente independente dos outros", o que irá caracterizar a ausência de subordinação (SILVA, 2010, p. 108-109).

Essa divisão impõe a observância em especial quanto ao ativismo judicial, que tem construído um mundo próprio, violando todos os preceitos constitucionais normatizados e garantidores de direitos. Utilizando-se de decisóes com fundamentos morais, e não de direito propriamente dito, o Judiciário tem se investido num papel que náo é seu.

$\mathrm{Na}$ tentativa de moralizar a política, o Judiciário utilizando-se do ativismo, deixa sua passividade institucional, e passa a legislar, desde normas gerais a abstratas. Apesar de toda a corrupção e do apelo pela moralizaçáo, o que o Judiciário esta fazendo vai de encontro ao Estado Democrático de Direito e a própria representação política e à democracia representativa.

Conforme afirma Streck (2007, p. 40), essa nova perspectiva estatal surge impulsionada pela necessidade do resgate das promessas não cumpridas da modernidade, dentre elas a igualdade, a justiça social, a democracia material e a garantia dos direitos humanos fundamentais, na qual "a lei (Constituição) passa a ser uma forma privilegiada de instrumentalizar a ação do Estado na busca do desiderato apontado pelo texto constitucional, entendido no seu todo dirigente-valorativo-principiológico”.

Aliado a isso, o crescente descrédito da classe política e das instituiçóes parlamentares, o predomínio dos interesses econômicos na própria definição das políticas públicas e a mercantilização da Democracia tem levado o Judiciário a lidar com caminhos que o 
colocam em verdadeiros dilemas éticos, pois de um lado é necessário dar uma resposta à demanda apresentada e, de outro, sabe-se, que se transformam em verdadeiros atentados à autonomia, independência e separação dos poderes. Cruz (2006, p. 240-241) destaca que o ativismo judicial inserido no Brasil, mostra um mundo no qual o juiz é quase um ente "transcendentalmente superior" que tudo pode.

O modelo clássico de Estado de Direito encontra-se em crise, a democracia representativa, cada vez mais minada por conta do gradativo processo de fragmentação da soberania. Em decorrência fragilidade política atual de muitos países, como o Brasil, na tentativa de moralização política, o Judiciário, muitas vezes, utilizando-se de ativismos, deixa sua passividade institucional e passa a legislar, desde normas gerais a abstratas.

Contudo, o sistema constitucional garante aos Partidos Políticos ${ }^{6}$ a autonomia e liberdade, que fazem parte da prerrogativa constitucional de associação, o que inclui a possibilidade de participação não apenas do pleito, como também no processo de financiamento das agremiaçóes. E verificou-se, por exemplo, diante de uma decisão proferida pelo Supremo ${ }^{7}$ a retirada tais garantias, com base em argumentos morais. Um ativismo judicial, já que se esta tratando de matérias próprias, essenciais à preservação dos procedimentos democráticos, cuja alteraçáo, seria em tese de exclusiva competência legislativa.

Ferrajoli (2010, p.02) destaca, que "pertence à esfera de discricionariedade do decidível as funçóes de governo, nas quais podemos incluir tanto as funçóes legislativas, como aquelas stricto sensu governativas". Contudo, as funçóes de garantia, que estâo na esfera do indecidível, são exercidas pelo judiciário, que em decorrência do princípio da legalidade, possui "uma natureza tendencialmente cognitiva".

Nas palavras de Ferrajoli (2010, p.06) "quanto maior for o grau de efetividade das garantias substanciais e processuais, tanto mais rígida e certa será a separação entre legis-latio e juris-dicto e, portanto, o limite entre a jurisdição e a política”. Dessa forma, as garantias constitucionais, devem ser o mais certas possíveis, para que a própria política possa "salvaguardar o próprio papel do legislativo e reduzir a discricionariedade dos juízes, vinculando-os à sujeição perante a lei”.

6 Os Partidos Políticos, nesse contexto, constituem corpos intermediários entre o povo e o Estado canalizando a vontade social, de fundamental importância para a construção democrática, e estáo envoltos de princípios balizadores, como a soberania nacional, o próprio regime democrático, a soberania popular, o pluripartidarismo e pluralismo, e a separação dos poderes.

7 Ação Direta de Inconstitucionalidade n.4560/DF - O acórdáo da referida decisão ainda não esta disponível no site do Supremo Tribunal Federal, tendo sido publicada apenas a decisão de julgamento (disponível em: http://www.stf.jus.br/portal/diarioJustica/verDiarioProcesso.asp?numDj=75\&dataPublicacaoDj=22/04/2014\&incidente $=4136819 \& \operatorname{cod}$ Capitulo $=2 \&$ numMateria $=8 \& \operatorname{codMateria}=3$ ) 


\section{Conclusões}

Não há como separar a ideia de representação política dos Partidos da construção da cidadania, para o fortalecimento da democracia. São eles, os Partidos, os atores intermediários entre o povo e o Estado, que irão canalizar a vontade popular, fazendo parte da vida da sociedade e da construção democrática.

De fato, o modelo clássico de Estado de Direito encontra-se em crise, a democracia representativa, cada vez mais minada por conta do gradativo processo de fragmentação da soberania e da fragilidade política atual. Contudo, a soberania popular somente se efetiva na construção democrática, através da representação política, nos termos do parágrafo único da Constituição Federal, através de representantes eleitos ou diretamente.

Os Partidos Políticos, nesse viés, são aglutinadores de interesses individuais na formação da vontade política coletiva, e juntamente com a garantia dos direitos políticos como prerrogativas atreladas à cidadania, quando outorgam à população o direito de participar da escolha das decisóes políticas, devem englobar e harmonizar democraticamente os anseios da sociedade.

Adotado o modelo garantista, que com sua releitura do positivismo clássico, mostrase como importante e vantajoso instrumental à sociedade contemporânea, que vê seus direitos muitas vezes vilipendiados por ativismos judiciais, buscando uma guinada no pensamento normativo do direito, como forma de garantia, atrelado à legalidade própria do Estado de Direito. A partir do momento, que direitos constitucionalmente garantidos, começam a ser vilipendiados por decisóes judiciais, muitas vezes baseada em preceitos morais, passa-se a viver numa constante insegurança jurídica.

Este trabalho concentrou-se na análise dos institutos pertinentes à temática proposta, não houve, portanto, a pretensão de esgotar o tema ora investigado, já que é por demais amplo, complexo e divergente para que pudesse ser pesquisado no âmbito de um artigo.

Contudo, a transformação da sociedade e do Estado é nítida e tem interferido diretamente no ritmo das relaçóes intersubjetivas, e vem lutando cada vez mais pelo fortalecimento da cidadania. Em decorrência do esvaziamento da política e da descrença na democracia, que é imprescindível e desafiante o fortalecimento de instituiçóes como a representação política e o próprio Partido Político, de forma transparente e clara, para que se concretize uma verdadeira democracia representativa. É imprescindível oferecer respostas de forma mais célere às demandas sociais, justamente como forma de fortalecimento da democracia representativa e da cidadania.

\section{Referências}

ARENDT, Hannah. On revolution. New York: Viking, 1965 
ALEXY, Robert. Teoria de los derechos fundamentales. Trad.: Garzón Valdes. Madrid: Centro de Estudios Políticos Constitucionales, 1997.

BAUMANN, Zigmunt. Vida Líquida. Rio de Janeiro: Zahar, 2007. . Em busca da Politica. Rio de Janeiro: Zahar, 2000

BANDEIRA DE MELLO, Celso Antônio. Representatividade e democracia. In. VELlOSO, Carlos Mário da Silva, ROCHA, Carmem Lúcia Antunes (coord.). Direito Eleitoral: a reforma eleitoral e os rumos da democracia no Brasil. Belo Horizonte: Del Rey, 1996.

BASTOS, Celso Ribeiro, MARTINS, Ives Gandra. Comentários à Constituição do Brasil: promulgada em 5 de outubro de 1988. São Paulo: Saraiva, 1989.

BOBBIO, Norberto. Da estrutura à função. Trad. Daniela Beccaccia Versiani. São Paulo: Manole, 2007. . O futuro da democracia. 10. ed. São Paulo: Paz e Terra, 2006.

. Teoria do ordenamento jurídico. Trad. Maria Celeste dos Santos. Brasília: UNB, 1991.

BONAVIDES, Paulo. Ciência Política. São Paulo: Malheiros, 1997.

. Curso de Direito Constitucional. 20. ed. São Paulo: Malheiros, 2007.

BORJA, Rodrigo. Derecho politico y constitucional. 2 ed. Mexico: Fondo de Cultura Económica, 1991.

BRASIL. Constituição da República Federativa do Brasil. Brasília, DF: Congresso Nacional, 1988).

CANOTILHO, José Joaquim Gomes. Direito constitucional e teoria da Constituição. 7. ed. Coimbra: Coimbra Editora, 2008.

CANOTILHO, José Joaquim Gomes, MOREIRA, Vital. Constituição da República Portuguesa. 3. ed. Coimbra: Coimbra Editora, 2003.

CERRONI, Umberto. Teoria do Partido Político. Trad. Marco Aurélio Nogueira e Silvia Anette Kneip. São Paulo: Livraria Editora Ciencias Humanas, 1982.

CONDE, Enrique Alvarez. Curso de derecho constitucional. Madrid: Tecnos, 1999.

DUVERGER, Maurice. As Modernas tecnocracias. Trad. Natanael Caixeiro. Rio de Janeiro: Paz e Terra, 1978.

. Ciência Política: teoria e método. Trad. Heloísa de Castro Lima. 2. ed.Rio de Janeiro: Zahar, 1976.

. Os regimes políticos. Trad. Geraldo Gerson de Souza. São Paulo: Difusora Européia do Livros, 1962. 
. Os partidos politicos. Trad. Cristiano Monteiro Oiticia. 3. Ed. Rio de Janeiro: Guanabara. 1987.

. Sociologia política. Trad. Maria Helena Kühner. Rio de Janeiro: Forense, 1968.

FERRAJOLI, Luigi. Constitucionalismo principialista e constitucionalismo garantista. Trad. André Karam Trindade. In: Garantismo, hermenêutica e neoconstitucionalismo. Porto Alegre: Livraria do Advogado, 2012, p.13-56.

- Jurisdição e consenso. Revista Brasileira de Estudos Constitucionais -RBEC, Belo Horizonte, ano 4, n. 16, out/dez.2010. Disponível em: www.bidforum.com.br/bid/ PDI0006.aspx?pdiCntd=724556 - Acesso em: 22 jun.2015.

HABIB, Sérgio. Brasil: quinhentos anos de corrupção: enfoque sócio-histórico-jurídico-penal. Porto Alegre: Sergio Antonio Fabris Editor, 1994.

HAMILTON, Alexandre; MADISON, James; JAY, John. O Federalista. Tradução de Hiltomar Martins Oliveira. Belo Horizonte: Editora Lider, 2003.

HESSE, Konrad. A força normativa da Constituição. Porto Alegre: SAFE, 1991.

HOBBES, Thomas. Leviatã ou Matéria, Forma e Poder de um Estado Eclesiástico e Civil. Trad. João Paulo Carneiro e Maria Beatriz Nizza da Silva. São Paulo: Nova Cultural, 1997.

JARDIM, Torquato. Direito Eleitoral Positivo. Brasília, DF: Livraria e Editora Brasília Jurídica, 1998.

JELLINEK, Georg. Teoría General del Estado. Trad. Fernando de los Ríos. Buenos Aires: Editorial ALbatros, 1981.

KELSEN, Hans. A democracia. São Paulo: Martins Fontes, 2000.

. Teoria Pura do Direito, Trad. João Baptista Machado. São Paulo: Martins Fontes, 1991.

. Teoria Geral do Direito e do Estado. Trad. Luis Carlos Borges. São Paulo: Martins Fontes, 1998.

KINZO, Maria D’alva Gil. Radiografia do quadro partidário brasileiro. São Paulo: Fundação Konrad-Adenauer-Stiftung, 1993.

. Partidos, Eleiçóes e Democracia no Brasil Pós-1985. Revista Brasileira de Ciências Sociais, Vol 19 n. 54, fevereiro/2004.

KLEIN, Antonio Carlos. A importância dos partidos politicos no funcionamento do Estado. Brasília: Brasília Jurídica, 2002.

LOCKE, John. Segundo Tratado sobre o Governo Civil. Trad. Magda Lopes e Marisa Lobo da Costa. Petrópolis: Vozes, 1999). 
MARCELlinO JUNIOR, Julio Cesar. Princípio Constitucional da Eficiência: (des)encontros entre economia e direito. Florianópolis: Habitus Editora, 2009.

MEZZAROBA, Orides. Introdução ao Direito Partidário Brasileiro. Rio de Janeiro: Lúmen Júris, 2004.

Partidos politicos: princípios e garantias constitucionais, Lei 9.096/95, anotaçóes jurispridenciais. Curitiba: Juruá Editora, 2008.

MILL, John Stuart. Consideraçóes sobre o governo representativo. Trad. E. Jacy Monteiro. São Paulo: IBRASA, 1964.

MICHELS, Robert. Sociologia dos Partidos Politicos. Trad. Arthur Chaudon. Brasília: UNB, 1982.

MORAES, Alexandre de. Constituição do Brasil interpretada e legislação constitucional. $8^{\mathrm{a}}$ ed. São Paulo: Atlas, 2011.

MONTESQUIEU. O Espirito das leis.Trad. Cristina Muracho. Sao Paulo: Martins Fontes, 2000.

PINSKY, Jaime \& PINSKY, Carla Bassanezi (org). História da cidadania. 2ed. São Paula: Contexto, 2008.

PITKIN, Hanna Fenichel. El Concepto de Representación. Trad. Ricardo Montoro Romero. Madrid: Centro de Estudios Constitucionales, 1985.

. Representação: palavras, instituiçóes e ideias. Revista Lua Nova, n. 67, 2006, p. $15-48$.

ROUSSEAU, Jean-Jacques. O contrato social. Trad. Antonio de P Machado, 17 ed. Rio de Janeiro: Ediouro, 1996.

RUFFIA, Paolo Biscaretti di. Derecho Constitucional. Trad. Pablo Lucas Verdu, 3 [ ed. Madrid: Tecnos, 1987.

SAES, Décio Azevedo Marques de. Cidadania e Capitalismo: uma crítica à concepção liberal de cidadania. São Paulo, Caderno n. 8 do Instituto Avançado da Universidade de São Paulo, abril de 2000.

SANTOS, Boaventura de Sousa. Pela mão de Alice. O social e o político na Pós-modernidade. São Paulo: Cortes, 1995.

SILVA, José Afonso da. Curso de Direito Constitucional Positivo. 32. ed. São Paulo: Malheiros, 2010.

. Poder constituinte e poder popular: estudos sobre a Constituição. São Paulo: Malheiros, 2000. 
STRECK, Lenio Luiz. Neoconstitucionalismo, positivismo e pós-positivismo. In: Garantismo, hemenêutica e neoconstitucionalismo. Porto Alegre: Livraria do Advogado, 2012, p.59-94.

. Hermenêutica jurídica e $(m)$ crise: Uma exploração hermenêutica da construção do Direito. 7 ed., ver. e atual. Porto Alegre: Livraria do Advogado, 2007.

VELLOSO, Carlos Mario da Silva; AGRA, Walber de Moura. Elementos de Direito Eleitoral. São Paulo: Saraiva, 2014. 